\title{
PEDAGOGY
}

\section{SOCIO-CULTURAL ACTIVITY MANAGERS PRACTICAL TRAINING FEATURES}

\author{
Vladyslava Liubarets, Dr. \\ National Pedagogical Dragomanov University, \\ associate professor the Department of Management and Innovative Technologies, Social and Cultural \\ activities, Ukraine, Kiev
}

DOI: https://doi.org/10.31435/rsglobal_sr/31032019/6383

\section{ARTICLE INFO}

Received 11 January 2019

Accepted 23 March 2019

Published 31 March 2019

\section{KEYWORDS}

manager,

socio-cultural activity, innovative approaches, culture,

formation.

\begin{abstract}
The article deals with theoretical aspects of innovative approaches to practical training of socio-cultural activity managers as an innovative component of management, in particular its essence, types, specificity of innovative approaches. The interpretation of concepts of culture, inculturation, socio-cultural activity and the necessity of integrating these subjects into the practical training of managers of socio-cultural activities is substantiated. The definitions of "directions of socio-cultural activity", "profile of practically directed aspirations of the socio-cultural activity manager ", etc. are proposed. The typing of innovative approaches has been developed and their priorities for using in the practical training of managers of the socio-cultural sphere in Ukraine have been outlined.
\end{abstract}

Citation: Vladyslava Liubarets. (2019) Socio-Cultural Activity Managers Practical Training Features. Science Review. 3(20). doi: 10.31435/rsglobal_sr/31032019/6383

Copyright: (C) 2019 Vladyslava Liubarets. This is an open-access article distributed under the terms of the Creative Commons Attribution License (CC BY). The use, distribution or reproduction in other forums is permitted, provided the original author(s) or licensor are credited and that the original publication in this journal is cited, in accordance with accepted academic practice. No use, distribution or reproduction is permitted which does not comply with these terms.

The process of formation and development of professional management orientation of sociocultural activities managers is carried out continuously throughout the life cycle of professional activities. Professional orientation, regardless of the nature of the profession, has no definitive limits in its completeness. The specificity of the working conditions and the sphere of activity of the sociocultural sphere managers forms a special psychological composition of the personality of the representatives of this profession, whose views and ideas are largely evolving due to experience, perceptions, expectations, projections and prospects.

The purpose of the article is to analyze the scientific achievements in the field of activity of the socio-cultural sphere managers, to substantiate the conceptual ideas of training managers of sociocultural activities as an innovative component of management education, to offer definitions of innovative approaches to the practical training of managers of socio-cultural activities

The professional and practical orientation of the future profession connects a person not only with the profession, but also with the whole world. The structure of this process plays an important role in senses and meanings, specific situations and experience. Professional orientation as a subjective state of an individual can be changed in accordance with the emerging needs, tasks of the specialist, his goals, values, under the influence of professional activity.

The starting point for realizing the professional orientation of the socio-cultural activity manager is the professional-management process in the socio-cultural sphere, where a specialist can realize himself as a person, showing his professional qualities as proof of his professionally oriented ability.

Innovative approaches to the practical training of future managers are widely presented in the works of Y. Vasiliev, G. Gabdullina, V. Krichevsky, Y. Konarzhevsky, M. Potashnik, V. Maslova, 
R. Shakurov. Scientific research devoted to the problem of the preparedness of the chief, in particular, the manager of the socio-cultural sphere for management activities, are presented in the works of V. Bondar, T. Burlayenko, L. Danilenko, G. Dmitrenko, O. Dubinina, L. Kalinina, V. Maslova, V. Oliinik, T. Sorochan. The following foreign and domestic scientists as N. Bakhmat, N. Bibik, V. Baidenko, I. Zyazyun, N. Kuzmina, I. Kolesnikova, M. Lukyanova, A. Markova, A. Ovcharuk, E. Rogov, B. Slastionin, V. Serikov, O. Savchenko, M. Stepko, L. Horuzha were engaged in problems of forming the professional competence of future managers. The analysis of works on the problem of competence (N. Bakhmat, A. Bronskaya, T. Burlayenko, T. Hayvoronskaya, O. Dubinina, I. Zyazyun, M. Yevtukh, A. Markova, V. Kunitsina, E. Tabakova) allows us to consider the practical preparation of managers of socio-cultural activity as a quality of a personality, its installation, professional, pedagogical and psychological knowledge and skills [5].

The development of market relations in socio-cultural activities has largely changed the mission, goals and objectives of its functioning, updated the methods and principles of governance. The dynamic processes of labor division, showing in the renewal of social functions, roles and statuses of modern specialists, have deepened their specialization in various fields of socio-cultural activity: management, intellectual, artistic, cultural-creative, leisure, communicative, and others. The tendency to deepen the specifics of different activities today objectively became an important factor in the overall socio-cultural progress.

Culture, education, leisure culture, social pedagogy, etc. have the key influence on socio-cultural activity in the process of labor division. In other words, these are the directions of activity that are the closest to a person, his spiritual, moral, artistic development, his social health and social protection.

Culture is a product of collective life of people, and its individual creators and performers act as individuals. Traditionally, each individual advocates in relation to culture at the same time in several hypostases: as a "product" of culture, introduced in its norms and values, trained in technology activities, ethics of relationships with other people in the process of their inculturation and socialization, carried out in the course of childhood education, when receiving general and special education, in the process of contact with the social environment.

Inculturation is the process of entering the individual into the culture, mastering ethno-cultural experience. The main content of inculturation is the assimilation of the peculiarities of thinking and action, behavioral patterns that make up culture [7]. In the Oxford Encyclopedia, socialization is treated as a complex process of mastering the system of knowledge, norms and values that enable it to function in society [5, p. 270].

An important scientific work of T. Kiselyova and Yu. Krasilnikov is the synthesis of the semantic essence and functional significance of socio-cultural activity, which is characterized as a certain system of ideas and conceptions, reflecting the goals and functions of the state social policy in the field of culture and leisure, which defines the ways, methods and means their implementation in the conditions unfolding in the country processes of reforming socio-economic and social life [4].

Consequently, the structure of socio-cultural activities is organically represented by science, education and practice. The subject field of this science has a rich background in the field of cultural and educational work, and new trends aimed at scientific, educational and practical activities: cultural and leisure activities, social pedagogy, sociology of culture, applied cultural studies, and others.

The very concept of "socio-cultural activity", due to a wide range of problems, has no unambiguous interpretation, but each of the existing concepts enriches this multifaceted phenomenon with new facets and aspects, like a multi-valued interpretation of the notion "culture".

Socio-cultural activities can be considered in two senses:

- in the broad sense - as a way of human existence, as a system of inherited experience, as a material and spiritual environment that will contribute to the formation and elevation of man;

- in the narrow sense - as a certain form of people's life, including the preservation and use of cultural and historical heritage (museum, library, archival affairs, national and local traditions), artistic education, creativity, leisure and entertainment organization, amateurism, ethnography, crafts, as well as provides the form (management, economics, computer science, training and retraining of specialists) and the formation of their professional orientation as objects and subjects of socio-cultural activities.

The etymology of the concept of "socio-cultural activity" from the outset implies the activity nature of the processes taking place in this area, in which the professional orientation develops. Structurally, this activity, according to scientists [4], proceeds in three main directions: 
- economic, where the predominant place in the socio-cultural activity characteristic is occupied by such categories as public expenditure and profitability, costs and investment development, efficiency, self-sustainability, material security;

- humanitarian, covering a wide range of content and modern technologies of socio-cultural activity, which includes a whole block of initial concepts of social work, leisure, socio-cultural sphere, social purpose, principles and functions, private and sectoral techniques, domestic and foreign experience;

- organizational and managerial, where the basis of content-forming structures is the concept of management in the socio-cultural sphere, centralization and decentralization, democracy and selfgovernment, control and reporting, socio-cultural diagnostics, forecasting and designing.

A common feature of the socio-cultural sphere manager activities is the high level of systematization of these objects. In other words, the object of the manager's activity is a holistic complex open system in which the cognitive activity of the manager can and should cover both the entire system as a whole (object) and its individual elements (the individual aspects of the object groups, institutions and organizations). At the same time, professionally directed manager's activity should take into account the maximum of system connections of the object, both intra-system and with other objects (systems). This, in our opinion, is one of the characteristic features of virtually directed activities of the manager in the socio-cultural sphere.

According to the basic idea of the system theory, a holistic socio-cultural system consists of many elements that are connected by various interconnections. It represents a generalized, aggregate result of many social and cultural components, such as finite elements (active and mass cultural activities of people); interconnection of elements (sociocultural connections, interpersonal relationships, cultural exchanges, interactions, communication, etc.); functions of elements of the system as a whole (the need for certain cultural normative actions for the preservation of culture); border (expansion of opportunities for inclusion of people in cultural processes); subsystems (the number of teams of amateur creativity, amateur associations and interest clubs and other club formations); environment (creation of conditions for cultural activities, interaction with neighboring socio-cultural systems) [6, p. 47].

Based on this we can conclude that it is the specifics of the object of activity that determines the content of the subject matter of the activity of the manager of socio-cultural activities, and the nature of the implementation of his professional orientation.

The wide range of the practical aspirations of the manager of socio-cultural activity is realized at the level of assimilation of the types of activity characteristic of the whole cycle of interaction with the object-system. Manager as a specialist with a high degree of orientation in his professionally oriented activities does not experience great difficulty in transferring (if necessary) the main types of activity to other subject areas previously unknown to him [9].

A wide range of professionally directed interests of the manager of socio-cultural activities, meanwhile, does not mean the blurriness of his qualifications, the ability and readiness to solute a rather narrow and specific type of tasks without additional adaptation.

Implementation of the professional orientation of the socio-cultural activity manager is ensured, in our opinion, by the optimum ratio of general and specific types of professional tasks to be solved, the level of stability of professional and practical orientation, formed by the institution of higher education (IHE), according to the customer (state, institutions and organizations) goals, as well as specific to IHE culture and arts traditions of fundamental vocational education.

The unifying idea in all areas of knowledge in the management of socio-cultural activities is to seek ways of spiritual and practical improvement of the life of each separate individual, based on the uniqueness of his individual situation and the general laws of human existence. The lack of a sufficient level of mastery of higher education by basic knowledge in the future will prevent the way of obtaining the information and practical knowledge necessary for the formation of professional skills. This is shown in the limited narrow vocabulary of professional terminology. In our view, the systematic use of innovative approaches in the educational process can fill all these gaps, aimed at realizing the practical and social significance of the chosen profession of socio-cultural activities manager [9].

The leading theoretical foundations of professional competences of specialists in this field are cultural knowledge. At the same time, knowledge of the basic statements of theory and history of culture or cultural studies is only general awareness. Such awareness is a necessary component of any socio-humanitarian education. But for the formation of a well-trained specialist in the field of 
management of socio-cultural activity, such general awareness is not enough. General awareness cannot be considered a professional competence if it cannot be directly used in professional practice.

The purpose of practical training of socio-cultural activities managers is the assimilation of sufficient amount of scientific representations for professional work in the field of socio-cultural activities organization. This purpose defines the main tasks of their practical training were defined: formation of representations of higher education graduates about socio-cultural activity and management as a set of various types of professional work; awareness of the higher education students of the sphere of socio-cultural activity and management in the modern society as a set of branches organized according to the laws of the production economy; consolidation the essence of sociocultural production in modern society as a sphere of business understanding of the future specialist of this specialty; assimilation the ideas about the initial steps of the technology of self-formation of own workplace in the field of management of socio-cultural activities by future specialists; studying the higher education students of this specialty the historical and modern technologies of management of socio-cultural activity through the prism of their authorship and individually developed and tested means of market realization of socio-cultural products.

Defining the goals and objectives of the practical training of socio-cultural activities future managers is the basis for the formulation of according to which the content of the main disciplines of the professional cycle is revealed. Such semantic concepts are political, legal, social and economic requirements that are conditioned on the formation and development of a new direction in higher education, the provision of sustainable human development on a planetary scale, proclaimed by the United Nations in 2015, known as the Global Sustainable Development Goals or the 2030 Program» The development of professional competences of socio-cultural activities specialists in Ukrainian IHEs in their world-view and ideological bases and technological components must reflect the challenges of sustainable development. A productive semantic concept in the socio-cultural activities future specialists' formation is the modern demand for the risks reflection in the existence of humanity and the development of strategies for their limitation. The risk-based approach is organically linked to the requirement of sustainable development.

The realities of the domestic system of higher education today also demonstrate the lack of large-scale and systematic work towards the institutional and methodological provision of such an operational response, including work on the development of professional standards with a clear vision of the necessary competencies of the manager of socio-cultural activities, and the ordering of principles and algorithm for studying the socio-cultural needs of different categories. The population, which should be the basis for developing high-quality educational programs [8, p. 23].

One of the effective mechanisms for solving these problems is the introduction of a dual model of education that can ensure the acquisition of the necessary theoretical knowledge and practical competences by specialists in the field of socio-cultural activity management.

The experience of training specialists in leading European countries, in particular in Germany, is built on the dual form of education, has already shown that such an organization of the educational process is most effective in modern conditions, especially for those specialties requiring in-depth theoretical knowledge, mobility, communication skills and ability to solve complex problems.

The peculiarities of the dual form of education is the increase in the amount of education directly at the bases of practice, in the workplace (roughly $40 \%$ of the total educational program).

Dual approaches in training specialists in socio-cultural activities management are being implemented today through: the practical content of the curriculum of a specialty; provision of a crosscutting practical component (work in organizations and institutions of social and socio-cultural spheres); involvement of practitioners for conducting classes; provision of flexible schedule for the possibility of conducting classes on the basis of enterprises, institutions, public organizations; active forms of educational work, lectures, practical classes in small subgroups, trainings, case and design methods; self-study with counseling support of a teacher; formation of skills of project activity and implementation of project technologies; the active use of information technology for the search and processing of information, mobile communications and work in the virtual space.

It is important to note that the effectiveness of the system of dual education is provided through the consistent and systematic implementation of these basic approaches and principles and the shared responsibility of all participants in this process - teachers, employers and students themselves, without motivated and active work, no positive result is possible. 
In this context, it is important to emphasize the importance of a high level of accountability for higher education graduates who study under the dual model of education. At the same time, such responsibility is significant both in terms of higher requirements for the level of organization and discipline of students who already at this stage of studying learn to understand the features of each particular organization, respect its traditions, appreciate the time and efforts of future colleagues, and in terms of the forming the professional competences of future managers who have to implement the specified qualities in their activity [8, p. 25].

In modern methodological research in the management of higher education, the traditional category of personal orientation in educational activities is revealed and re-thought as a requirement of a student-oriented educational process. Principles of implementation of a person-oriented approach to learning were repeatedly disclosed by domestic and foreign researchers - teachers and psychologists. Many times, the implication of this approach in technology teaching and educational work in school took place $[2 ; 3]$. Sufficiently the following advantages of personality-oriented technology education were proved as the promotion of self-development of the individual, his successful socialization, self-defense, self-education, identity. These technologies provide not only the usual satisfactory adaptation of the person to the social environment, but also its productive integration into society. In the field of higher education, the importance of deepening a person-centered approach is even more important. Taking into account the level and prospects of student development, its needs, abilities and efforts is of particular importance in the first year of study, while the transition from school to the new educational environment takes place. The conditions for integration into the society are mastering the mechanisms of social communication, ideological orientations, and algorithms of joint active activity. Successfully integrated individual becomes a socially active person, realizes the resources of individual and group freedom, the prospects of realizing their own creative potentials, social needs and requirements for personal and joint activity. The means of person-oriented technologies provide cultural self-identification.

Conclusions. Thus, it can be argued that the use of innovative approaches to the practical training of managers of the socio-cultural sphere is an important component of education management. Given the high profile, the basic component of the practical training of the manager of socio-cultural activities is the use of basic innovative approaches, among which we distinguish: risk-taking, dual, and person-oriented approaches.

Further research perspectives are related to the development of functions of managers of socio-cultural activities and the formation of standardized models of competences of future managers of the socio-cultural sphere.

\section{REFERENCES}

1. Burlaenko T.I. Formation of economic competence of the manager - the way to the formation of a management elite / / Problems of education. No. 80 November 2014, pp. 42-44.

2. Dmitrenko GA, Anufriyeva OL, Burlayenko T.I. Man-centered system of state governance in Ukraine: utopia or chance: monograph; for community edit G. A. Dmitrenko. Kiev: DKS-center, 2014. 240 p.

3. Giddens E. Sociology. Part VII Glossary: Basic concepts and most important terms [Electronic resource]. URL: http://www.gumer.info/bibliotek_Bucks/ Sociolog/gidd/23.php.

4. Dvoretsky I. Kh. Latin-Russian Dictionary. OK. 50,000 words. Izd. 2nd 1096 s. Moscow: Russian language, 1976.

5. Encyclopedia for specialists in the social sphere / For the colleagues. edit I. D. Zvereva. - Kyiv, Simferopol: The Universe, 2012. 536 p.

6. Likhvar V.D., Podolskaya E.A., Pogorelij D. E. The Newest Dictionary of Culture. Terms, biographical information, illustrations // Ed. Spivak A. Moscow: Phoenix, 2010. 411 p.

7. Modern dictionary on cultural studies / Red. V. V. Yurchuk. Minsk: Modern Word, 2009. $736 \mathrm{p}$.

8. Shcherbyna-Yakovleva O. Yu., Svitylo N.D., Klochko M.O., Shcherbyna A.M. Management of sociocultural activity as a direction of scientific and technological knowledge. Part 1. Didactics, logic, methodology. Tutorial; sciences edit O.Yu. Shcherbyna-Yakovleva Deposited manuscript. Sumy, SSU Repository, 2018. 207 pp.

9. Bakhmat N, Dudka T., Lubarets V. Multimedia education technologies usage as the condition for quality training of the managers of socio-cultural activity // Information technologies and learning tools. Vol. 64 No. 2 (2018). P. 98-109. URL: https://journal.iitta.gov.ua/index.php/ittl/article/view/2027/1327.

10. Dubina O., Hrytsiak L. Use of information technologies in future project managers' activities // Information technologies and learning tools. Vol. 63. №1. 2018. P. 107-115. URL: https://journal.iitta.gov.ua/index.php/itlt/article/view/2038. 